\title{
Philosophers' debt to their students: The South African case
}

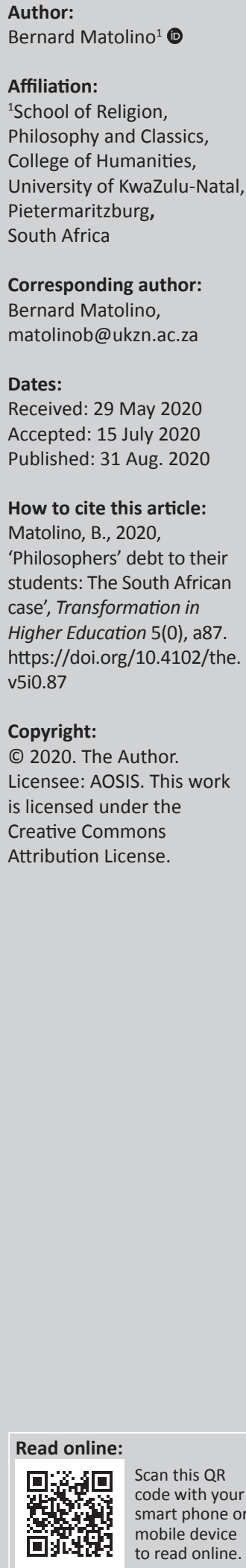

\begin{abstract}
Philosophy teachers owe their students a little more than mere formal instruction of topics popular in philosophy. What they owe their students is largely influenced by philosophy's claims to be a discipline that is principally dedicated to the study and fostering of wisdom. Therefore, there is an obligation to be wise on the part of philosophy teachers so that they can deliver that wisdom. A big part of this would involve a sort of transformation in knowledge and character that the teachers themselves must go through as a result of engaging in philosophy. Such transformation will not only show in ways that philosophers live their private lives, as wise people, but will certainly show in the topics they teach their students and how they help their students to wisely respond to their environment through an enlightened, relevant and empowering curriculum. If philosophers fail at this task, they will only dispatch fragmented pieces of information about philosophical topics and method that are of no use to their students. If philosophers are unable to see the shortcomings of this approach, then they can just as well count themselves unfit to be called (wise) teachers but technical philosophers. The fees must fall and Rhodes must fall movement coupled with demands for decolonisation, caught philosophers underprepared for such demands from students. Hence, in this article, I seek to examine the legitimate demands for transformation of the curriculum and how philosophical instruction in the country contributed to this protest, which eventually was caricatured in some sections as unreasonable. I argue that beyond what appears as unreasonable demands by students, there is an obligation by philosophy teachers to be responsible and responsive to the students' context in what they teach.
\end{abstract}

Keywords: philosophy; South Africa; fees must fall; philosophers' obligation; decoloniality.

\section{Introduction}

In this article, I seek to present what I consider to be philosophers' obligation to their students, as university teachers, in the South African context in the aftermath of the fees must fall movement and calls for the decolonisation of the curriculum. I argue that the problem may be located in philosophers abdicating their role as practitioners in a field that demands that they be wise. In concentrating on the technical aspect of philosophy (such as validity, proper names, brains in a vat, justification, etc.), to satisfy philosophical standards of the global North, philosophers have contributed to the creation of an intellectual vacuum amongst their charges, which has contributed to calls for the curriculum to be decolonised. However, this crusade for decolonisation suffers the fate of a not so well-informed binary view of the world. Whilst it is understandable where this binary view emerges from, what is not clear is its real purpose. I argue that the reason for this loss, at least in philosophy, is because of philosophy teachers having abdicated their responsibilities to impart wisdom - as philosophy's definition prescribes. For a country like South Africa, the university instruction of philosophy has been the greatest betrayal of the young generation by a professoriate that has a long history of irrelevance to its context. Such irrelevance is galling not only for its lack of contextual sensitivity, but also for its capacity to mislead a whole generation that (philosophy) teachers have been tasked with forming into wise and well-informed citizens. As a result of the abdication of responsibility to be wise teachers, philosophers have contributed to the cementing of views of a world of binaries that has fermented violence and absurdities in the university itself. This article is divided into three sections, the first is a brief outline of the historical problem and how it has led to the present stagnation, the second is pointer to what needs to be done in the instruction of philosophy in South Africa and the third attempts to sketch the benefits of following the instruction I suggest in the second section.

\section{Philosophy's past problems haunting the present}

Whilst violence accompanying the fees must fall movement was shocking to many who witnessed it, it was long time coming to many others (see Xaba 2017). Some actions and rhetoric that were 
deployed were far from civil and bordered on hate speech (Hodes 2016:147), which universities are tasked with defeating. The political origins of the fees must fall moment lies in the basic structure of South Africa as a severely divided society, the effects of which were felt by some enrolled students at the university (Langa n.d.). The legitimate and justified complaint was that certain sections of the society were being denied a university education by virtue of their historical material deprivation, which is steeped in the history of apartheid and racial discrimination (Oxlund 2016). This history created a class of generally well-off citizens (who happen to be white) whilst confining the majority (who happen to be black) to a fate of material deprivation and financial insecurity, which reduced their access to facilities that could better their lives (Oxlund 2010:33-35). Denial of access to higher education on the grounds of financial inability, in the country of one's birth, is a gross injustice that was correctly pointed out by the fees must fall movement. I am not going to pursue this line in any detail as it is not the target of this discussion. Rather, what I am interested in is the spin-off from the fees must fall that came to be known as the call for the decolonisation of the curriculum (Le Grange 2016). This call was mainly centred on the university's failure to transform its structures, which led to the exclusion of certain groups, the professoriate so that it becomes demographically representative and epistemologies so that they can be reflective of the context in which teaching was happening (and effectively stop the promotion of Western epistemology at the expense of African epistemology). This last complaint was also to be known as advocacy of the Africanisation of the curriculum (Ally \& August 2018). I am interested in tracing the link between philosophy's past failures and the demand for Africanisation as it emerged in calls made by agitated students. If that link can be proven, then philosophy's culpability in these events is great, and the figures behind these developments must take full responsibility.

Of all the notorious political systems that this world has seen, there is no doubt that South Africa's apartheid system was one of the vilest to an extent that it was declared a crime against humanity (see Lingaas 2015). This declaration shows how wicked apartheid was as a political project. Nothing was commendable about it, if anything, it only succeeded in attaining a criminal status as the declaration indicates. Philosophy, unfortunately, was complicit in the misdeeds of apartheid. Wolff's (1986-87) assessment of philosophy in English-speaking South African universities, following his visit in the 1980s left him no option but to strongly condemn its manner as insensitive to the fact that it was being carried out in a fascist background. In the same manner, More (1996) insisted that the majority of philosophers in the country were indifferent to the fate that befell their fellows who, in the struggle for freedom, were victimised by the apartheid regime.

In the midst of apartheid's atrocities, what is clear is that in the division that existed between continental and analytical philosophy in formerly white South African universities, the intent was replication and pursuit of Western traditions. At the margins of these endeavours were African universities that were denied both the space and materials to pursue African-centred forms of knowledge. African universities simply replicated the banality of African lives in the broader society as second class and inconsequential. In contrast, Afrikaans universities benefitted from state sponsorship that ensured that Afrikaans was turned into a scientific language that enabled both instruction and publication (Kamwangamalu 2004:206).

Overall, formerly white universities pursued their teaching and research in ways that showed complete apathy to the environment they operated in. There was absolutely no political or intellectual pressure for these public institutions to be of benefit to the greater members of the population. Philosophy was right in it. Never bothered by the political and social injustice around it, and not prepared to comment on that injustice, South African philosophers made careers out of studying Western philosophers. For generations, careers were carved out of writing and lecturing on Western thinkers and traditions.

What can we make of philosophy's general silence and failure to condemn apartheid? I think there are three ways of approaching this question. ${ }^{1}$ One way would be to say that most of the individual philosophers who practiced their trade during apartheid did not really know what was happening in the country. It could be said that although they cared deeply about justice and the fate of all human beings, including black South Africans, the apartheid regime did such a brilliant job of misleading its white citizens that they did not have a real understanding of what the situation was for black people. It is very hard to believe this line of thinking. Whilst it is true that the apartheid regime was engaged in acts of disinformation, it remains to be seen how white people (individually or collectively) reacted to information that contrasted the apartheid regime's propaganda. Further, it also remains to be seen what the silent whites thought of their fellow whites who openly denounced apartheid and decisively threw their lot with the cause of black people. Indeed philosophy had such a citizen in the person of Rick Turner. $^{2}$ A second way would be to see white people as genuinely committed, but mistakenly so, to what they believed to be their cause. They could have believed that black people were actually asking for too much, and that if blacks could only behave properly everything would be alright. They could have believed that some or all black political leaders were trouble makers who were bent on causing trouble for no good reason but to cause trouble. They could have believed that whilst their government acted excessively, in some cases, it was always provoked to act the way it did and those actions were for the good of everyone in South Africa as they contributed to the maintenance of order.

1.I do not seek to suggest these ways as exhaustive but merely illustrative of possible commitments.

2.Rick Turner (1941-1978) was a white South African radical philosopher who was assassinated in his house (possibly for his political activism). 
A third way would be to see white people during apartheid as believers in differences that existed between black and white people. They could have thought that culturally, intellectually and morally - white people were different from black people. What that difference could have implied is that white people were to be held to a higher standard that black people were incapable of, hence these racial groups could not expect to enjoy the same benefits. White people could have operated with a certain notion of history that placed white achievements at the top and blacks right at the bottom. They could have been aware of the history of ancient and modern civilisations that consistently showed white people to be more cultured than black people. They could have thought that whilst individual black people could be trained to be skilled in one or two trades (even all the way to becoming medical doctors), they were not good enough to collectively form a culture that would be comparable with white culture. They might also have thought that white culture was simply too advanced. For this reason they just sought to get on with the experience of being white, whilst they also allowed blacks to be blacks.

Whatever the truth for the reasons of white attitudes could be, it matters little as black people were systematically discriminated against and abused by the white establishment. What is important is that any possible attitude that white people had against black people or to explain the differences imposed by apartheid, were simply not true. One can push the matter further by arguing that white people who fell victim to these beliefs were intellectually and morally dishonest. Many philosophers who practiced their trade in white universities were particularly dishonest by their failure to demand the normalisation of society, purely on philosophical grounds. There was enough written on notions of justice and equality in their books that should have made them think carefully about the African's situation and how apartheid could, at least theoretically, be failing both black and white citizens.

However, as professional philosophers did nothing of the sort, we can say that they implicitly acquiesced with apartheid's underlying logic of creating superiority and inferiority amongst racial groups in the country. The philosophy they pursued and practiced was meant to benefit the group that was seen as superior and was of no import to the group that was deemed inferior. Intellectually, they did not care about the environment they operated in. This lack of care led to an abdication of their responsibility to their own situation. This is quite an astounding achievement, as philosophers are normally people who prioritise questions and views from their environment as they tend to show deep concern for it. This is not just a personal commitment that philosophers choose for themselves or are guided by, rather it is simple logic of philosophy itself. Jones (2006) supported this thinking when early on in his own essay on philosophers' moral obligation to their environment he wrote:

I have become sympathetic to the thought that philosophers, in our roles as philosophers, have responsibilities to respond to our context, and this essay is a defense of this claim. The upshot of the essay is that philosophers should be aware of, concerned with, and working on philosophical issues that arise in their context, and that this responsibility is a moral one. The Accusation may or may not in any one case be appropriately targeted at a philosopher or philosophical community, but the idea behind Accusations - that philosophers have responsibilities and are susceptible to a judgment of negligence - is, I shall argue, correct. (pp. 624-625)

As philosophy is grown by thinkers who are in a particular environment that is shaped by its own local facts and proclivities, they should attempt to attend to and prioritise their local experience before seeking to claim their universal (philosophical) citizenship. With the South African situation, there was no attempt at developing South African philosophy (through engagement with South African issues), but there was commitment to furthering Western philosophy. That, in all probability, was an indication of where the cultural commitments of the philosophers lay. Whilst there were philosophy, philosophy departments and philosophers during apartheid, there was no South African philosophical tradition, and what was bequeathed post-apartheid South Africa was nothing South African.

In the aftermath of the end of apartheid, when all manner and forms of change were occurring, philosophy retreated into a space of privileged exclusion of questions of the day. Philosophy, as it was practiced during apartheid, continued unperturbed by the transformation and other events around it. Philosophy departments, in formerly white universities, continued identifying themselves either as analytical or continental. Not only did they identify themselves as such but these two traditions competed for influence in both the official philosophical society in the country and its journal. This competition culminated in a nasty confrontation, at the 2007 annual meeting of the society, between a representative of agitators for continental philosophy and well targeted then editors of the South African Journal of Philosophy who were accused of favouring the analytic tradition (see Spurrett 2008:154, footnote 2). However, philosophy's inability to transform itself and be sensitive to its environment came to a head in a very nasty way in the national society's meeting, when a new generation of black South Africans, clearly fed up with the way of doing business called philosophers' racism out ${ }^{3}$ as well as the deliberate ignoring of African philosophy. So huge was the effect of that indictment, the incident was reported in a respected weekly and the society probably suffering from extreme guilt went into voluntary suspension whilst it took stock.

These are the shenanigans of philosophy in South Africa! But behind all these farcical commitments to Western dogmas and resolute ignoring of the local, there was serious harm that was being done. The short-sightedness of philosophers under apartheid and their belief that they could continue with the same approach two decades into a free South Africa, shows a serious lack of wisdom and sound judgement.

3.The events leading up to and after this encounter were reported in the national press: https://mg.co.za/article/2017-02-07-no-one-philosophical-about-demise-of philosophical-society/ 
This is particularly so if one considers that philosophy departments, in the country, are largely staffed by South African citizens. Their failure to be responsive to their 'backyard' is not only inexcusable but damaging. One can imagine how the public funds that were used to maintain philosophy and people staffing those departments actually never benefitted the public. One can regret how so much potential talent and education was wasted on far away concepts at the expense of never explored home-grown concepts. One can imagine how useless the discussions on Plato's ideas of democracy were, in South Africa, whilst apartheid raged. It was this useless and irrelevant philosophy that was handed over to the generation that demanded a decolonised curriculum. If this generation was taught Descartes's musings on himself as a thinking thing, on Kant's duties and utilitarianism's bewildering theories and anything of that sort, they probably had every right to feel short-changed, undermined and mis-educated. A ready justification for this façade is found in Wolff's (2016) thinking on, or reaction to, demands for curriculum transformation when he writes:

Quite regularly in debates about the curriculum, it is mentioned that students - here black students - in general have an experience of estrangement due to the course content. What is taught at university does not fit into what they learn at home, it is often said. But in my view this is not necessarily a problem. I remember very well, for instance, how some of my own classmates experienced the confrontation of the racism they had picked up at home with anti-racism at varsity - with salutary effect. If staunchly creationist students of biology are shocked by the theory of evolution, I sympathise, but do not see this as sufficient reason to change the biology curriculum. There are a number of reasons why, in philosophy too, students may have to deal with a tension between what they have learned at home and what they study in class. These remarks are not intended to dismiss the reported experiences of some students. Such reports may be a way in which cultural bias in the curriculum is registered. My point is that there is no direct correlation between students' disorientation by study material and the illegitimacy of teaching such material. (p. 455)

One can see from this passage how dismissive Wolff is of black students' estrangement and their demands for curriculum transformation. That transformation by the way is not primarily to satisfy black students' private comforts or continue with providing them with the familiarity of their home prejudices. On the contrary, it is a moral obligation for academics to be sensitive to the context of the majority of the students they teach. For Wolff to dismiss such a context as equivalent to some white students' experiences of racism or creationism, which are challenged at university is mischievous. It is mischievous because the two instances he equates to black experiences of alienation and demands for transformation are actually instances of ignorance and unworthy bias. The disorientation he describes black students to experience is not a matter of mere home-reared bias. It is deeper than that as it goes to the politics of privilege at university and who has the privilege to ignore what and incorporate what as genuine knowledge - particularly in humanities (philosophy included).
What Wolff represents is a long-standing defence of a façade that hides an equally long-standing need by South African philosophers. The need of recognition! Recognition by the colonial metropole that they were able to replicate the research expertise and teaching competencies of the prestigious universities of the world. This, charitably, is a result of the global hierarchies of knowledge that exist and are said to be true. Hence, there is an expectation that leaders in the fields of knowledge will be from these universities and the best that the rest of the world has to do is to keep with them. However, this view, is not useful for agitated students who feel excluded in systems of their third world and perennially 'developing' countries. The students see this as coloniality and demand that it should end.

\section{The demand for decolonial education and what needs to be done}

The demand for decolonial education was carried out by eager but not so well read, sophisticated, advantaged or knowledgeable professors. It was mainly carried out by students who were expressing their impatience and anger at not only being materially excluded in the country of their birth through grinding poverty, but who were also feeling very angry about how higher education was structured in ways that made the acquisition of knowledge more suited to certain sections of society than others. However, because these agitated students were confronting their welleducated teachers, who believed that they had a superior intellect and had real interests to defend, the students' real arguments were routinely ridiculed, shown to be juvenile, ambitious and misdirected. Also, the accompanying violence of the students' demands did not help their cause in the slightest. Whilst I do believe that the students were correct in their call for decolonised education, the call got lost somewhere in the violence of the fees must fall movement that came with it.

The first problem that the students encountered was that they lacked a coherent theoretical outline of what the programme of a decolonised curriculum would actually entail. Even their lecturers were not so sure what decoloniality was. Costandius et al. (2018) wrote:

During the group discussion on decolonisation, lecturers agreed that the term has not been defined well enough. Many students and lecturers do not know what decolonising the university means. Lecturers asked: 'What does decolonisation stand for? Who is asking it? Can we move to decolonisation if we don't have a shared way of thinking about where we want to go?' Lecturers called for the creation of a unified definition of decolonisation within each institution and faculty, which must be communicated to other institutions and faculties. (p. 75)

Although this study's focus was Stellenbosch University, I don't think it is an exaggeration to generalise this ignorance to almost all universities, particularly former white universities. Former black universities were not even well 
equipped to provide intellectual succour to this burgeoning theoretical demand as they had never exhibited desire for, or competence at it.

Thus, the students fell into a dangerous trap. The trap is decoloniality itself as an academic subject - from the humanities. The concept and practice of decoloniality has been raging for as long as Africa has been free with various approaches to interpreting or understanding its major tasks. As Gatsheni-Ndlovu (2015) wrote:

Decolonial movements assumed various forms and terms such as Ethiopianism, Garveyism, Negritude, Pan-Africanism, African Socialism, African Humanism, Black Consciousness Movement, and African Renaissance. Thus, unlike simple anticolonialism, decoloniality was and is aimed at setting afoot a new humanity free from racial hierarchization and asymmetrical power relations in place since conquest. (p. 488)

On the next page, we get further information on the nature of decoloniality when Gatsheni-Ndlovu (2015) continues:

Decoloniality names a cocktail of insurrectionist-liberatory projects and critical thoughts emerging from the ex-colonized epistemic sites like Latin America, Caribbean, Asia, Middle East, and Africa; it seeks to make sense of the position of ex-colonized peoples within the Euro-America-centric, Christian-centric, patriarchal, capitalist, hetero-normative, racially hierarchized, and modern world system that came into being in the 15th century. (p. 489)

From the identity of decolonial movements, one gets a myriad of commitments that are all tied together by the desire to get rid of racial hierarchies. However, two points are noteworthy. The first is that some of these movements have come under sustained criticism for either their simplicity or inability to advance African people's cause. I have in mind criticism raised against Negritude and African socialism. Negritude as a theory of knowledge has been dismissed as an epistemological framework that caricatured Africans as naive and unresponsive to reason. With Senghor's insistence on emotion as a mode of knowing, debates have raged on whether such a method is justified or whether it is sufficient for the purpose for which it was invented - a counter to white supremacy (see Masolo 1994:27; Mudimbe 1988:92, 94). African socialism has been shown to be a discredited political theory that has led to material impoverishment of citizens whilst contributing to the stifling of individual rights and freedoms (Alofun 2014:71).

The second problem for decoloniality is the description it earns as insurrectionist. I do not want to think that this is an unfortunate choice of words, but an apt description of the real aim of the project of decoloniality. It is literally insurrectionist. This means that it might have a single interpretation of the problem as well as the method necessary to address the problem.

Thus, the trap that decoloniality provides, exists at the conceptual and practical level. At the conceptual level, in order to develop any concept that is described as decolonial, in any sense, one must have a firm grasp of world events of colonialism, philosophies and histories of racism as well as reasons behind these commitments. One must have an almost perfect knowledge of the intricacies of the epistemologies they are going to oppose, the grounds on which those epistemic frames have been universalised and how they have come to be dominant. One must have an excellent knowledge of how these thinkers' context was and how they related to that context, which turned them into committing to their epistemologies and accompanying claims of superiority or universal validity. This in itself is no easy task. Not only does it require a degree of sophistication and formal education, but it requires serious expertise that universities judge by conferring titles that affirm such expertise. Taking an example drawn from philosophy, my favourite philosopher in decolonial theory is Emmanuel Chukwudi Eze. Eze was a man who was immensely talented; he was widely read and highly knowledgeable as can be seen from his work. He died at a relatively young age (44) in 2007. At the time of his death, he was an associate professor at De Paul University and he had just completed his book, On Reason: Rationality in a World of Cultural Conflict, which was published posthumously. Eze is recognised as an expert in the philosophy of the enlightenment. $\mathrm{He}$ is particularly interested in what was responsible for making the enlightenment's major philosophers committed to racism. In his in-depth study of philosophers such as Kant and Hume, he gives insightful detail of what could have led them to committing to their positions. Firstly, at the general level, he argues that modern masters of Western philosophy have been obsessed with the topic of 'man'. This obsession was in part fuelled by the Westerner's encounter with different human beings, which led him to ask if there was a serious difference between himself and these other men. A part of enlightenment philosophy was to account for that difference. For Kant, Eze demonstrates, his approach to race was informed by his interests in anthropology, which he followed for a whilst before 'changing' to philosophy. For Hume, Eze shows, his interest in the difference of operations of reason lay in his epistemology and politics, which was committed to a form of reason that favoured abstract thought. Through both the effort to categorise human beings into different varieties as well as a preference for a certain form of reason as human, the exclusion of the black race was completed in the enlightenment. In his On Reason, Eze (2008) gives a comprehensive account of the nature of reason as it has been used in the West. He shows what the peculiarities and shortfalls of that use were. However, he has an insightful view of the origins, strengths and weaknesses of different forms of reason as used in different contexts. His major aim is to show that reason is not to be divorced from its context. However, in the fifth and last chapter of that book, a chapter devoted to South Africa - ubuntu in particular, Eze changes his argument. In that chapter, Eze makes a compelling argument that if ubuntu is to succeed as a philosophical project there is need for it to be separated from politics. What this means is that whilst ubuntu may be seen as a political project, it can also be seen as a philosophical endeavour. 
Once there is misunderstanding of how far the political aspect may be allowed to encroach the philosophical space, then philosophising on ubuntu will be hindered by political considerations.

My reason for using Eze is to illustrate how complex the issue of decoloniality is. In part it is a reaction against a set frame of thinking that is steeped in a history and context of discrimination. Not only does one have to be an expert at what he advocates, he must also be an expert at what he opposes. As Eze does, there is need to go beyond the appearance of thought to discover what is behind that thought. But there is also need to be fully aware of the pressures that bear on our systems of thought. We must be able to separate burdens of analysis from political burdens so that we can be true to the calling of philosophy. At the same time we must be able to judge and separate versions of philosophy that pretend to be universally valid from those that are genuinely of use to our context. This is not an easy task. It has many levels of conceptual analysis that require the sort of dexterity that is expected from leading scholars.

Tragically, in the South African space, such philosophical competence and insight had been marginalised. Students were then left to forage for usable concepts in aid of articulating their struggle and what they came up with was Fanon and Biko. The problem with the usage of Fanon's ideas on violence, in particular, proved to be handicap for the students' movement at two levels. Firstly, theoretically the students failed to see the possibility of engaging with the world that did not create Fanonian distinctions steeped in confrontation. It was as if, for them, there were no other usable approaches to decoloniality that did not invoke dichotomies. For example, Tuck and Yang (2012) read Paulo Freire's thinking as the complete opposite of Fanon's, hence they wrote:

Fanon positions decolonization as chaotic, an unclean break from a colonial condition that is already over determined by the violence of the colonizer and unresolved in its possible futures. By contrast, Freire positions liberation as redemption, a freeing of both oppressor and oppressed through their humanity. Humans become 'subjects' who then proceed to work on the 'objects' of the world (animals, earth, water), and indeed read the word (critical consciousness) in order to write the world (exploit nature). For Freire, there are no Natives, no Settlers, and indeed no history, and the future is simply a rupture from the timeless present. Settler colonialism is absent from his discussion, implying either that it is an unimportant analytic or that it is an already completed project of the past (a past oppression perhaps). Freire's theories of liberation resoundingly echo the allegory of Plato's Cave, a continental philosophy of mental emancipation, whereby the thinking man individualistically emerges from the dark cave of ignorance into the light of critical consciousness. (p. 20)

Given South Africa's trajectory of peace and reconciliation was started by Mandela, we could ask if the students ever considered the question was the trajectory advocated by Freire not more useful towards contributing to the Mandela project. Of course not, that is why Mandela was vilified by their movement as a sell-out. Yet, at another level, the very violent nature of this moment was based on the Fanonian masculinisation and understanding of violence, which excluded all other forms of protest, resulting in patent criminal acts such as rape and roughing up of lesbian activists, as Xaba (2017) argued.

The second problematic aspect of decoloniality is its practical aspect. As Gatsheni-Ndlovu affirms, decoloniality is an insurrectionist-liberatory approach to the experiences of colonialism. What this means is that the attitude adopted by adherents of decoloniality will be in line with what is demanded by insurrectionist-liberatory practices. This may include glorification of violence as an effective mode of dethroning colonial systems. The origins of this attitude is understandable. There was a time when the only option, to successfully confront, colonial regimes was through violence of varying degrees. This led to the launching, sponsorship and justification of insurrectionist movements and military outfits. These outfits were armed by sympathetic countries such as China and the USSR with friends that were dotted around the globe. Countries such as South Africa, Angola, Zimbabwe, Namibia and Mozambique (in Southern Africa) saw armed wars for independence and freedom. These wars are a perfect example of decolonial campaigns of an insurrectionist-liberatory kind. They also provide a reference to what genuine decolonial campaigns look like.

However, what must be recognised is that wars of liberation have their relevance and context. Whilst they may serve as inspiring events for future generations to contemplate upon or refer to, once they have attained their goal, their use begins to fade into the background. Pseudo-militant language, styles and approaches to present day problems may actually be of limited effect. Yet these traits were clearly on display in the fees must fall and decolonial moment. Revolutions or violence as a means to an end has the potential to delegitimise otherwise a legitimate cause, if circumstances that justified use of violence have changed or disappeared. Whilst supporters of the cause may justify the use of violence as the only resort available to register their discontent, there is no assurance that such tactics actually succeed in addressing root causes of problems such as structural inequalities and real reasons behind them Westernised university curriculums. In any event the state, through the police, showed the students who actually had a monopoly on violence.

What I, therefore, think needs to be done is something akin to Eze's (2006) suggestion that the teaching of philosophy in universities needs an upgrade. Whilst Eze's argument is aimed at improving philosophy so that it can be in conversation with other specialisations in the sciences, the upgrade I have in mind is of a different form. Philosophy in South Africa needs to be upgraded from both the apartheid curriculum and the decolonial insistence. Both these approaches present dangers that need to be avoided. The apartheid form is a relic that has no relevance and use in our present context. Decolonised philosophy, on its own, is insufficient to skill our students the way philosophy students should be skilled. 
The upgrade I propose involves genuinely taking into account what the purpose of philosophy is in any given environment. Philosophy operates in its environment as an attempt to respond to a set of questions that are significant to both professional philosophers and ordinary people. Those questions are significant because they arise in the course of people living their lives or as people begin to reflect on their lives. As life is lived and experienced, there will always be questions and searches for either answers to issues that are not clear or inquiries into what is not clear or what needs attention. Some of these questions will not be philosophical but other questions will be of a philosophical nature. If the questions are of a philosophical nature, then philosophers with all their skills may intervene and attempt working out possible philosophical responses or offer philosophical insights. What must not be disputed is that each human environment, in its totality is different from other human environments. Factors such as history, beliefs, how evidence is treated and what knowledge is taken to be are going to differ from one place to another. In addition, social factors that may bring people together or divide them play an important role in how each group and its individual members view reality, their relations to other groups and what they think is their justified expectation of how society should treat them. If all these factors are taken into account, the specific demands that a place has on philosophers to create a philosophical environment that is reflective of the distinctness of that place, become all too clear. The situation in South Africa is that of dichotomies and philosophy has tended to reproduce the unproductive parts of these dichotomies. By remaining white both in composition and topics of preference, it has only become a continuation of its environment rather than reflect on that environment of dichotomies.

Philosophy needs to upgrade to a status of integrating the myriad voices that compete in determining questions that arise in the public space. Especially questions that its citizenry (its students) may encounter on a day to day basis. African students who have a radically different experience of life from their professors are not expecting too much when they enter into classes with the hope that the philosophy they will be taught will be relevant to their lives. Any professor who teaches philosophy that is not relevant to such students can rightly expect to have his relevance questioned. As Baumgarten (1980) wrote:

The work of philosophy teachers is thus a form of service to others, and it is open to ethical assessment according to the degree to which it benefits students, 'those who are subject to it'. (p. 185)

Whilst it is fair to note that there are as many voices as there are students and claimed identities, it is the job of professors to deliberately make their philosophical encounters or instruction be about the contestation over reality that has become characteristic of this country. My argument is not that priority should be given to some view about what this place is about; rather, my argument is that philosophy must be open to this place. It must begin to be comfortable about the place it operates in so that it can originate in this place. The only way to achieve this is for philosophy itself to engage its place in ways that show the seriousness that the place deserves. For a long time, this place has been treated as if it could not fit into philosophical discussion, or when it is made to fit into philosophical discussion, a special category is created for it under dubious descriptors such as 'we offer a course in African philosophy'. This is a misnomer as Africa is part of the name of this country and Africa should be foundational to the philosophical experience in this country. This, without any ambiguity, is the debt that philosophers have to their students.

\section{Possible benefits}

I propose that there are some benefits that are likely to accrue to students as a result of the foregoing. If philosophy curriculums were fundamentally reformed to be reflective of the major concerns (both living and conceptual) of this place, then the demand for decolonisation will fall away. The demand for decolonisation will not fall away because the curriculum would have been decolonised and would now be offering courses that are essentially Africanised and stripped of all undue influence of colonial influences and continued control by former colonial metropoles. Sensitivity to the requirements of a place is broader than narrow and unclear demands for decoloniality. Decoloniality, particularly on the African continent, both as an intellectual ideal and political practice has never genuinely empowered the citizens of this continent. As a theory it has remained locked at the level of trying to work out what it is and what its potential effect is. At the practical level all forms of decolonial experiments and programs have ended in disaster with Africa, materially, firmly at the bottom of all nations.

What I think more productive is an approach to teaching philosophy that empowers the students and liberates the professors. One way in which professors of philosophy may be liberated is for them to acknowledge, and transmit that acknowledgement as academic knowledge, that they are in a discipline that is historically racist (and sexist). Western philosophy, with its claims of origins in Greece, has always been tied to historical episodes of the expansion of the empire. Alexander and Aristotle, the slave trade and the enlightenment philosophers are just but two prime examples that need serious philosophers to be frank about when they stand in front of first year students. Whilst Kant, Hume, Marx and whoever are brilliant thinkers who are seductive and powerful when their ideas are properly taught and understood, there is a dark side to them about how they enabled the universalisation of division amongst races and inferiorisation of the black race. If their ideas are taught, in context, the students would be truly empowered to develop the historical appreciation that Eze refers to. At the same time, philosophers must also free themselves to be truly at home in their home. They should be able to teach those aspects of African history that are taken as highlights of African thinking. William Amo's refutation of Descartes, 
Charles Mills's reading of John Rawls, Emmanuel Eze's characterisation of reason and Kwasi Wiredu's view on decolonisation are all possible productive starting points of embracing the real presence of philosophy in blackness. Theirs is a philosophy that is not parochial, a philosophy that does not hide behind force and mysteries of black witchcraft and nightly operations but is based on operations and justification of reason. Ideas from all angles of the historical encounter of European reason and African reason, in the context of conquest, must be laid bare for the students to appreciate the world they live and operate in.

Two tragedies have besieged philosophy in this country to the detriment of the quality of philosophy students we produce. They are the tragedies of avoiding the philosophy of race and the tragedy of a partial (if not late and ineffectual half embrace of African philosophy). This tragedy is seen in the sort of absence of specialisation or influence that South Africa has in the philosophy of race. At the beginning of this essay, I bemoaned the bankruptcy of apartheid as a criminal exercise. Its criminal nature was primarily that it was racist. All the nefarious effects of apartheid proceeded from its racism. Yet philosophers in this country have largely decided to stay away from the issue of race and racism. Frankly, South African philosophers should be competing with their American counterparts in discussions of the problematic topic of race and racism. This is particularly so as race remains a determinant of a person's life chances and possibilities in South Africa, more than any other category. The tragedy of African philosophy is even farcical. There were not more than three black South African philosophers, in this country, on the eve of 1994. These thinkers had carried the light of African philosophy to varying degrees, but from 1994 to this day, South Africa, despite being so wellresourced, does not have research output in African philosophy, comparable to Ghana - a country with a much smaller population than South Africa. Another glaring tragedy is that South African philosophy departments have a very small number of South African (born) professors of African descent. Whilst some moves (as a result of pressures of equity targets), are being made to fill junior positions with South African (born) junior academics, a lot still needs to be done at most of the formerly white universities to achieve an acceptable representation of South African philosophers of African descent.

If these tragedies are overcome and university lecturers are freed from the bondage of the need to defend a certain view of philosophy at the expense of their place and environment and are willing to embrace the philosophical promise and actual achievements of this place, then we will possibly have a well-developed curriculum emerging from our departments. Such a curriculum, as mentioned, will be sensitive to history, the history of ideas and the role that philosophy has played in the development of both. Professors can only deliver the truth about these matters and students will be expected to reflect on them with integrity. By doing so, professors will invite students of all colours and creeds to a genuine journey of intellectual inquiry into the fickleness of humanity and the promise that humanity holds.

But most importantly, our students will begin to benefit from an education that is truly universal. If all aspects of philosophical reasoning and orientation was presented to students, equally, then students will have a better appreciation of their own place in the globe. Whilst it is true that we are connected in fundamental and meaningful ways, those connections need a bit of enunciation about where they start from and how they spread all over the world to create our current reality. I do believe that students who have such an understanding stand a better chance of appreciating their place, which gives rise to their philosophy and how it connects to the rest of the world. They become empowered citizens of the local and the global as they are able to explain the dynamic of their situation and what they can expect from the history of such a situation and what they take exception to. Such students begin to be truly knowledgeable students of the discipline as opposed to political agitators of a dogmatic orientation to the world. They will not always find the language of insurrectionist-liberatory approaches to knowledge to be the only way they can claim citizenship in the academe. Their language will be much richer than an insurrectionist dictum.

\section{Conclusion}

If this reads like an indictment, then maybe it should be. What I have sought to present is how the state of philosophy cannot be excused from the current crisis of decoloniality. It is a serious crisis that requires philosophy teachers to think about their own attitudes and what teaching and doing philosophy in the southernmost country on the African continent should be about. The approach to teaching philosophy, I have sought to defend, is one that does not seek to choose between dichotomies of Western curriculum and so-called indigenous knowledge systems. It will be a curriculum that shows awareness to the possibility that both intellectual traditions may contribute to the development of students as well-informed graduates.

\section{Acknowledgements Competing interests}

The author has declared that no competing interests exist.

\section{Author's contributions}

I declare that I am the sole author of this research article.

\section{Ethical consideration}

Ethical clearance was not needed for the study.

\section{Funding information}

This research received no specific grant from any funding agency in the public, commercial or not-for-profit sectors. 


\section{Data availability statement}

Data sharing is not applicable to this article as no new data were created or analysed in this study.

\section{Disclaimer}

The views and opinions expressed in this article are those of the authors and do not necessarily reflect the official policy or position of any affiliated agency of the authors.

\section{References}

Ally, Y. \& August, J., 2018, '\#Sciencemustfall and Africanising the curriculum: Findings from an online interaction', South African Journal of Psychology 48(3), 351-359. https://doi.org/10.1177/0081246318794829

Alofun, G.O.O., 2014, 'African socialism: A critique', IOSR Journal of Humanities and Social Science 19(8), 69-71. https://doi.org/10.9790/0837-19866971

Baumgarten, E., 1980, 'The ethical and social responsibilities of philosophy teachers', Metaphilosophy 11(2), 182-191. https://doi.org/10.1111/j.1467-9973.1980. tb00108.x

Costandius, E., Blackie, M., Nell, I., Malgas, R., Alexander, N., Setati, E. et al., 2018 'Fees must fall and decolonising the curriculum: Stellenbosch University students' and lecturers' reactions', South African Journal of Higher Education 32(2), 65-85. https://doi.org/10.20853/32-2-2435

Eze, E.C., 2006, 'What to do? Upgrade!', Topoi 25(1-2), 51-56. https://doi. org/10.1007/s11245-006-0007-0

Eze, E.C., 2008, On reason: Rationality in a world of cultural conflict and racism, Duke University Press, Durham, NC.

Gatsheni-Ndlovu, S., 2015, 'Decoloniality as the future of Africa', History Compass 13(10), 485-496. https://doi.org/10.1111/hic3.12264

Hodes, R., 2016, 'Questioning fees must fall', African Affairs 116(462), 140-150. https://doi.org/10.1093/afraf/adw072

Jones, W.E., 2006, 'Philosophers, their context, and their responsibilities', Metaphilosophy 37(5), 623-645. https://doi.org/10.1111/j.1467-9973.2006.00462.x
Kamwangamalu, N.M., 2004, 'The language planning situation in South Africa', in R.B. Baldauf \& R.B. Kaplan (eds.), Langage planning and policy in Africa vol 1 : Botswana, Malawi, Mozambique and South Africa, pp. 197-281, Multilingual Botswana, Malawi, Mozd
Matters Ltd, Clevedon.

Langa, M. (ed.), n.d., \#Hashtag: An analysis of the \#FeesMustFall movement at South African universities, Centre for the Study of Violence and Reconciliation, South African universities, Centre for the Study of Violence and Reconciliation,
Johannesburg, viewed 14 May 2020, from http://csvr.org.za/pdf/An-analysis-ofthe-FeesMustFall-Movement-at-South-African-universities. pdf\#page=8.

Le Grange, L., 2016, 'Decolonisation, higher education transformation, student protests and university curriculum', South African Journal of Higher Education 30(2), 1-12. https://doi.org/10.20853/30-2-709

Lingaas, C., 2015, 'The crime against humanity of apartheid in a post-apartheid world', Oslo Law Review 2(2), 86-115. https://doi.org/10.5617/oslaw2566

Masolo, D.A., 1994, African philosophy in search of identity, East African Educational Publishers, Nairobi.

More, M.P., 1996, 'Complexity, neutrality or advocacy? Philosophy in South Africa: Ronald Aronson's "stay out of politics": A review essay', Theoria: A Journal of Social and Political Theory 87, 124-135.

Mudimbe, V.Y., 1998, The invention of Africa: Gnosis, philosophy and the order of knowledge, Indiana University Press, Bloomington, IN.

Oxlund, B., 2010, 'Responding to university reform in South Africa: Student activism at the University of Limpopo', Social Anthropology 18(1), 30-42. https://doi. org/10.1111/j.1469-8676.2009.00095.x

Oxlund, B., 2016, '\#Everything must fall: The use of social media and violent protests in the current wave of student riots in South Africa', Anthropology Now 8(2), 1-13. https://doi.org/10.1080/19428200.2016.1202574

Spurrett, D., 2008, 'Why I am not an analytic philosopher', South African Journal of Philosophy 27(2), 153-163. https://doi.org/10.4314/sajpem.v27i2.31509

Tuck, E. \& Yang, K.W., 2012, 'Decolonization is not a metaphor', Decolonization: Indigeneity, Education \& Society 1(1), 1-40.

Wolff, R.P., 1986-87, 'Philosophy in South Africa Today', Philosophical Forum 18(2-3), 94-104. https://doi.org/10.1080/02580136.2016.1242200

Wolff, E., 2016, 'Four questions on curriculum development in contemporary South Africa', South African Journal of Philosophy 35(4), 444-459. https://doi.org/10.10 80/02580136.2016.1242200

Xaba, W., 2017, 'Challenging fanon: A black radical feminist perspective on violence and fees must fall movement', Agenda 31(3-4), 96-104. https://doi.org/10.1080/ 10130950.2017.1392786 